\title{
The Curley Effect: The Economics of Shaping the Electorate
}

\section{Citation}

Glaeser, E. L. and Andrei Shleifer. 2005. The Curley Effect: The Economics of Shaping the Electorate. Journal of Law, Economics, and Organization 21 (1): 1-19. doi:10.1093/jleo/ewi001.

\section{Published Version}

doi:10.1093/jleo/ewi001

\section{Permanent link}

http://nrs.harvard.edu/urn-3:HUL.InstRepos:27867137

\section{Terms of Use}

This article was downloaded from Harvard University's DASH repository, and is made available under the terms and conditions applicable to Other Posted Material, as set forth at http:// nrs.harvard.edu/urn-3:HUL.InstRepos:dash.current.terms-of-use\#LAA

\section{Share Your Story}

The Harvard community has made this article openly available.

Please share how this access benefits you. Submit a story.

\section{Accessibility}




\title{
NBER WORKING PAPER SERIES
}

\section{THE CURLEY EFFECT}

\author{
Edward L. Glaeser \\ Andrei Shleifer
}

Working Paper 8942

http://www.nber.org/papers/w8942

\section{NATIONAL BUREAU OF ECONOMIC RESEARCH \\ 1050 Massachusetts Avenue \\ Cambridge, MA 02138}

May 2002

We are grateful to the NSF and the Gildor Foundation for financial support, to Alberto Alesina, Elhanan Helpman, Caroline Hoxby, Lawrence Katz, James Robinson, Ken Shepsle, and Daniel Treisman for helpful comments, and to Jesse Shapiro and Andrei Goureev for research assistance. The views expressed herein are those of the authors and not necessarily those of the National Bureau of Economic Research.

(C) 2002 by Edward L. Glaeser and Andrei Shleifer. All rights reserved. Short sections of text, not to exceed two paragraphs, may be quoted without explicit permission provided that full credit, including $\mathbb{C}$ notice, is given to the source. 
The Curley Effect

Edward L. Glaeser and Andrei Shleifer

NBER Working Paper No. 8942

May 2002

JEL No. D70, D72, H4

\begin{abstract}
James Michael Curley, a four-time mayor of Boston, used wasteful redistribution to his poor Irish constituents and incendiary rhetoric to encourage richer citizens to emigrate from Boston, thereby shaping the electorate in his favor. Boston as a consequence stagnated, but Curley kept winning elections. We present a model of the Curley effect, in which inefficient redistributive policies are sought not by interest groups protecting their rents, but by incumbent politicians trying to shape the electorate through emigration of their opponents or reinforcement of class identities. The model sheds light on ethnic politics in the United States and abroad, as well as on class politics in many countries including Britain.
\end{abstract}

Edward L. Glaeser

Department of Economics

Harvard University

Littauer 315A

Cambridge, MA 02138

and NBER

eglaeser@harvard.edu
Andrei Shleifer

Department of Economics

Harvard University

Littauer M9

Cambridge, MA 02138

and NBER

ashleifer@harvard.edu 


\section{Introduction}

Early in the first World War, a wounded British officer arrived in Boston to recruit citizens of the then-neutral United States to fight in the British army. He politely asked the by then legendary Irish Mayor of Boston, James Michael Curley, for permission. Curley replied "Go ahead Colonel. Take every damn one of them." This statement captures Curley's lifelong hostility to the Anglo-Saxons of Boston, whom he described as "a strange and stupid race," and his clear wish that they just leave. Throughout his four terms, using a combination of aggressive redistribution and incendiary rhetoric, Curley tried to transform Boston from an integrated city of poor Irish and rich protestants into a Gaelic city on American shores.

Curley's motivation is clear. In his six mayoral races between 1913 and 1951, he represented the poorest and most ethnically distinct of Boston's Irish. The city's Brahmins always despised him because of his policies, his corruption, and his rhetoric, and always worked to block his victory. The probability that James Curley would win in Boston was, to a first approximation, strictly increasing in the share of poor Irish Bostonians, and strictly decreasing in the share of rich Bostonians of English descent. Unsurprisingly, he tried to turn Boston into a city that would elect him.

We call this strategy — increasing the relative size of one's political base through distortionary, wealth-reducing policies - the Curley effect. But it is hardly unique to Curley. Other American mayors, but also politicians around the world, pursued policies that encouraged emigration of their political enemies, raising poverty but gaining political advantage. In his 24 years as mayor, Detroit's Coleman Young drove white residents and businesses out of the city. "Under Young, Detroit has become not merely an American city that happens to have a black majority, but a black metropolis, the first major Third World city in the United States. The trappings are all there - showcase projects, blackfisted symbols, an external enemy, and the cult of personality" (Chafets 1990, p. 177). Zimbabwe's President Robert Mugabe abused the white farmers after his country's independence, openly encouraging their emigration even at a huge cost to the economy. 
The emigration through which the Curley effect operates need not be across geographic - city or national -- boundaries; it could also describe movement across social classes. Before Tony Blair, the British Labour party was always backed by wage laborers, and opposed by managers and entrepreneurs. Many of Labour's policies in such areas as taxation, nationalization, and education aimed to prevent the "embourgeoisement" of the working class and its political migration toward Conservatives. Not surprisingly, the British economy sharply underperformed its competitors.

In this paper, we focus on the Curley effect in the context of electoral politics, specifically, on destructive tax and public good policies that shape the electorate to the incumbent's advantage ${ }^{2}$. We focus on democracies, and on the voting mechanism in which each voter gets one vote. We assume that the incumbent wants to maximize the probability of his re-election, but do not treat the overall economic performance of the city or nation as the crucial determinant of that probability. In our model, ethnic or class identity, as well as redistribution to one's core constituency, shape electoral outcomes through emigration across geographic or class lines.

There are other manifestations of the Curley effect. Leaders in some democracies, and especially in dictatorships, physically eliminate or otherwise damage their opponents. Stalin's gruesome slaughter of the Kulaks and Mao's mass killings in the Cultural Revolution are also forms of the Curley effect, but electoral losses were not a concern to these dictators. Even in democracies, nationalization and regulation can deprive one's political opponents of resources usable in politics, as was done by the British Labour party after World War II, or by Mitterand in France in the 1980s. Such deprivation of resources can prevent lobbying for alternative policies or financial support of opponents.

Seen in this light, many of the most harmful policies of local and national governments result neither from a disinterested folly, nor from a garden-variety desire for

\footnotetext{
${ }^{2}$ We do not discuss some of the closely related strategies determining who can vote and how votes are "counted" for the final outcome, such as gerrymandering, politically motivated redistricting, and enfranchisement and disenfranchisement of different categories of voters.
} 
redistribution. Instead, these policies are motivated by a desire to alter the political landscape, including by shaping the electorate. Socially costly policies are attractive to the political leaders because they eliminate or weaken the political opposition.

The Curley effect turns traditional views about the requirements for good government on their head. Some distinguished observers (Olson 1993) argue that sufficiently forward-looking leaders will avoid policies that harm their electorate. But the Curley effect relies critically on forward-looking behavior: when it operates, longer time horizons raise the attraction of socially costly political conduct. Others follow Tiebout (1956) in arguing that large response elasticities to bad policies serve to limit them: "the fiscal discipline that is forced upon these units [local governments] emerges from the mobility of resources across subordinate governmental boundaries within the inclusive territorial jurisdiction" (Brennan and Buchanan 1980, p. 178). With the Curley effect, in contrast, large response elasticities make bad policies more rather than less attractive to incumbents.

In this paper, we formalize the Curley effect. We consider the two cases of geographic and social mobility. In both cases, the government can differentially tax different groups. In the case of geographic mobility, higher tax rates encourage emigration of one of the groups. In the case of social mobility, higher tax rates discourage investment in human capital, so the down-trodden stay down-trodden and do not "migrate" to a higher social class. In both cases, the incumbent leader raises taxes to increase the probability of his re-election. In both cases, these optimally chosen higher tax rates may actually impoverish the area and make both groups worse off.

We assume that the incumbent has an innate appeal to the lower status group. This appeal results from ethnic or class identity (e.g., Verba, Ahmed and Bhatt 1971, Akerlof and Kranton 2000), and is one of several determinants of the voting decision. Our model presents an alternative approach to the politics of ethnic division to that proposed by Alesina, Baqir and Easterly (1999), who focus on the variation in the preferences for public goods across ethnicities but do not consider changes in the 
electorate. In our model, ethnic division causes problems because politicians from one ethnic group pursue socially costly policies in order to eliminate the other ethnic group as political actors.

Our model follows the work on inefficient redistribution through public employment and other means (e.g. Alesina and Rodrik 1994, Persson and Tabellini 1994, Shleifer and Vishny 1994, Coate and Morris 1995, Alesina, Baqir, and Easterly 2000, Robinson and Verdier 2002). Our innovation is the idea that such wasteful redistribution shapes the electorate by influencing migration and education decisions.

Finally, our model is related to a large literature on the adverse consequences of redistributive policies on economic development. Typically, this literature takes the point of view that inefficient redistribution or other wasteful policies are sought by interest groups either seeking rents or protecting the existing rents (Grossman and Helpman 2001, Krusell and Rios-Rull 1996, Parente and Prescott 1999). In our model, by contrast, incumbent politicians rather than interest groups seek inefficient policies, because such policies help them get re-elected. The increased likelihood of re-election comes not primarily from the economic rents obtained by the supporters, but from reshaping the electorate through policies that either induce the incumbent's opponents to emigrate or alternatively keep his supporters from social mobility that might change their votes. Indeed, no economic benefits need to accrue to anyone for a policy to be attractive to an incumbent. In this respect, our paper is closer to the work that emphasizes the desire of incumbent politicians to stay in power (Brennan and Buchanan 1980, Olson 1993, DeLong and Shleifer 1993, and Acemoglu and Robinson 2000, 2002).

\section{A Model}

In this section, we formalize the basic elements of the Curley effect in a general voting model. In sections III and IV, we apply this model to emigration, and in sections $\mathrm{V}$ and VI to class mobility. In each case, there are two groups, or classes, or ethnicities in the jurisdiction, and all voters - as well as the incumbent -- belong to one or the other. 
The leader chooses how much to redistribute from the disfavored to the favored group. Denote the tax that he imposes on each member of the disfavored group by q, where $\mathrm{q}$ is the same for each member of that group. Here $\mathrm{q}$ equals zero when there is no redistribution, and is positive when the leader favors his own group. Note that q can also be interpreted as a bias in the provision of public services toward the favored group. Our main question is whether the leader chooses $q>0$ as opposed to $q=0$.

The benefit of this redistribution to the leader's group is also a function of the ratio of the number of voters in the competing group to the number of voters in his own group. We denote this ratio by $\pi$. If each member of the other group is taxed $q$ than each member of the leader's group receives $\tau \pi q$, where $\tau<1$ is a parameter that captures the waste associated with redistribution. In this model, redistribution is always inefficient: it makes the community as a whole worse off because it wastes resources.

We consider two settings. In the first, leaders influence the composition of the electorate as people migrate in response to the choice of q. In the second, change in the composition of the electorate comes from occupational choice or investment in human capital. Voters in effect choose their social class in response to policy q, and vote in part according to their social class. In this setting, a leader can discourage social mobility by redistributing from the rich to the poor. In either setting, we assume in this section that the value of $\pi$ is falling with $\mathrm{q}$, and later formally model the process (migration or occupational choice) through which redistribution alters the shape of the electorate.

\section{The Voting Process}

We use a simple voting framework: an incumbent maximizes the probability of his re-election. If more than 50 percent of the electorate prefer the challenger to the incumbent, the latter loses. Our discussion focuses on the relative preferences for two candidates. There are two central elements of our model of voting. First, voters care about the ethnic or class identity of the candidates (see Verba et al. 1971, Akerlof and 
Kranton 2000, and the literature on British politics cited below). This reflects the prospective feature of voting, since the identity of a candidate predicts his future policies. Second, the politician's past policies influence voters as well. This is a retrospective feature of the voting decision (Fiorina 1981, Alesina and Rosenthal 1995).

Each voter is assumed to get utility $\mu$ if the incumbent is re-elected and utility $v$ if the opponent is elected. Both $\mu$ and $v$ are random variables that vary among voters. We assume that $\mu-v=j+k$, where $\mathrm{j}$ is an individual level shock and $\mathrm{k}$ is an electorate level shock. The individual level shock is denoted by $\mathrm{j}$ and is symmetrically distributed around zero with density $g(j)$ and cumulative distribution $G(j)$. This component of preferences is completely random at the individual level, and entails no aggregate uncertainty. The electorate-level preference, denoted by " $\mathrm{k}$ " is symmetrically distributed around zero with density $\mathrm{f}(\mathrm{k})$ and cumulative distribution $\mathrm{F}(\mathrm{k})$. This preference generates uncertainty for the incumbent. We assume that the density functions $f($.$) and g($.$) are$ single-peaked and that the limits of $f($.$) and g($.$) as \mathrm{k}$ or $\mathrm{j}$ go to infinity are zero.

Voters also get utility from the leader's group (ethnicity or class) membership and policies. If a leader from the voter's own group is elected, the voter receives utility of $v_{0} / 2$. If a leader from the other group is elected, the voter receives utility of $-v_{0} / 2$. These preferences are independent of past policies and are best thought of as representing a pure taste for one's own ethnicity or class.

In addition to these group preferences, individuals respond to the incumbent's past policies. In particular, members of the leader's own group get utility of $v_{1}(\tau \pi q)$ if he is re-elected, where $v_{1}(0)=0$ and $v_{1}^{\prime}()>$.0 . Members of the other group get utility of $-v_{1}(q)$ if the leader is re-elected. The influence of past policies can be thought of as retrospective voting, as government patronage to buy votes, or as a measure of "consistency" of policies over time. 
Policies determine the outcome of the election in two ways. First, q has a direct effect coming through the tastes of the two groups. Second, q influences the composition of the electorate.

When the incumbent faces an opponent from the other group, members of his own group vote for him when $j>-\left(v_{0}+v_{1}(\tau \pi(q) q)+k\right)$ and thus his share of votes from his own group is $1-G\left(-v_{0}-v_{1}(\tau \pi(q) q)-k\right)$. Members of the other group vote for him when $j>-\left(-v_{0}+v_{1}(-q)+k\right)$, so his share of their votes is $1-G\left(v_{0}-v_{1}(-q)-k\right)$. Thus, conditional on $\mathrm{k}$, the share of votes that the incumbent receives equals:

(1) $1-\frac{1}{1+\pi(q)} G\left(-v_{0}-v_{1}(\tau \pi(q) q)-k\right)-\frac{\pi(q)}{1+\pi(q)} G\left(v_{0}-v_{1}(-q)-k\right)$

When the incumbent faces an opponent from his own group, its members vote for him when $j>-\left(v_{1}(\tau \pi(q) q)+k\right)$ and his share of their votes is $1-G\left(-v_{1}(\tau \pi(q) q)-k\right)$. Members of the other group vote for him when $j>-\left(v_{1}(-q)+k\right)$ and his share of their votes is $1-G\left(-v_{1}(-q)-k\right)$. Thus, conditional on $\mathrm{k}$, the share of votes that the incumbent receives when facing an opponent from his own group is given by:

(2) $1-\frac{1}{1+\pi(q)} G\left(-v_{1}(\tau \pi(q) q)-k\right)-\frac{\pi(q)}{1+\pi(q)} G\left(-v_{1}(-q)-k\right)$

We assume that that the opponent comes from the leader's own group with a fixed probability $\mathrm{p}$, from the other group with probability $1-\mathrm{p}^{3}$. The incumbent's share of votes then equals:

\footnotetext{
${ }^{3}$ We have also considered a case in which $\mathrm{p}$ is itself determined by the composition of the electorate. It yields qualitatively similar results.
} 


$$
\begin{aligned}
& P(q)=1-\frac{(1-p) G\left(-v_{0}-v_{1}(\tau \pi(q) q)-k\right)+p G\left(-v_{1}(\tau \pi(q) q)-k\right)}{1+\pi(q)} \\
& -\pi(q) \frac{(1-p) G\left(v_{0}-v_{1}(-q)-k\right)+p G\left(-v_{1}(-q)-k\right)}{1+\pi(q)}
\end{aligned}
$$

We use the notation $\hat{\pi}=\pi(0)$. Differentiating (3) with respect to q yields (at $\mathrm{q}=0$ ):

$$
\begin{aligned}
& P^{\prime}(q)=\frac{-\pi^{\prime}(0)(1-p)}{(1+\hat{\pi})^{2}}\left(G\left(v_{0}-k\right)-G\left(-v_{0}-k\right)\right)+ \\
& \left.\frac{\hat{\pi} v_{1}^{\prime}(0)}{1+\hat{\pi}}\left(\tau(1-p) g\left(-v_{0}-k\right)-(1-p) g\left(v_{0}-k\right)-p(1-\tau) g(-k)\right)\right)
\end{aligned}
$$

The symmetry of $\mathrm{g}($.$) implies that \mathrm{g}(\mathrm{x})=\mathrm{g}(-\mathrm{x})$. Thus, an increase in q raises the share of votes if and only if $\mathrm{P}^{\prime}(\mathrm{q})>0$ or:

(5) $\frac{-\pi^{\prime}(0)}{\hat{\pi}(1+\hat{\pi})} E_{k}\left(G\left(v_{0}-k\right)-G\left(-v_{0}-k\right)\right)>v_{1}^{\prime}(0) E_{k}\left(g\left(k-v_{0}\right)-\tau g\left(v_{0}+k\right)+\frac{(1-\tau) p g(k)}{(1-p)}\right)$.

This condition can be considerably simplified if we follow Grossman and Helpman (2001) and assume that " $\mathrm{j}$ " is uniformly distributed on the interval [-a/2, a/2], so $\mathrm{G}(\mathrm{x})=1 / 2+\mathrm{x} / \mathrm{a}$, and also that the variance of " $\mathrm{k}$ " is small enough so that the incumbent always receives some voters from both ethnic groups. In that case, the incumbent's share of the votes (conditional on $\mathrm{k}$ ) becomes

(3') $P(q)=\frac{1}{2}+\frac{k}{a}+\frac{(1-\pi(q))(1-p) v_{0}+v_{1}(\tau \pi(q) q)+\pi(q) v_{1}(-q)}{a(1+\pi(q))}$,

and increases in $\mathrm{q}$ (from zero) raise the probability of re-election if and only if: $\frac{-\pi^{\prime}(0) v_{0}}{\hat{\pi}(1+\hat{\pi})}$ is greater than $\frac{(1-\tau) v_{1}^{\prime}(0)}{2(1-p)}$. This condition gives the basic logic of the Curley effect, which is then generalized in the following proposition. The Curley effect occurs when the impact of policies on the shape of the electorate (i.e. $\left.-\pi^{\prime}(0)\right)$ is large, when 
ethnic preferences (i.e. $v_{0}$ ) are important, and when the waste involved in redistribution (i.e. $\left.(1-\tau) v_{1}^{\prime}(0)\right)$ is not too extreme. This generalizes directly to proposition 1 :

Proposition 1: Assume that $\tau<1, \frac{-\pi^{\prime}(0)}{(1-\tau) v_{1}^{\prime}(0)}>\frac{\hat{\pi}(1+\hat{\pi}) p}{(1-p)} E_{k}(g(k))$, and $\mathrm{g}$ "' $(\mathrm{j})$ is small. Then there exists a value of $v_{0}$, denoted by $v_{0}^{*}$, at which the incumbent does not want to redistribute (i.e., chooses $\mathrm{q}=0$ ). For values of $v_{0}$ above $v_{0}^{*}$, the incumbent strictly prefers redistribution, and for values of $v_{0}$ below $v_{0}^{*}$, he chooses $\mathrm{q}=0$.

(a) If we write $v_{1}(x)=\widetilde{v}_{1}(x)+v x$, then an increase in $v$ raises $v_{0}^{*}$.

(b) If $\frac{\partial \pi^{\prime}(0)}{\partial \tau} \leq 0$, then $v_{0}^{*}$ falls as $\tau$ rises.

(c) If we write $\pi(q)=\tilde{\pi}(q)-\pi_{0} q$, then $v_{0}^{*}$ falls as $\pi_{0}$ rises. More generally, $v_{0}^{*}$ rises with any parameter that increases the value of $\pi^{\prime}(0)$ (i.e. brings it closer to zero) falls with any variable that decreases the value of $\pi^{\prime}(0)$, as long as these parameters do not change $\hat{\pi}$.

(d) The value of $v_{0}^{*}$ rises with $\mathrm{p}$.

Proof: For all proofs see the appendix.

Two of the three conditions required for Proposition 1 to hold are fairly intuitive. The condition $\tau<1$ must hold so that there is some cost of redistribution-otherwise redistribution is always desirable at the margin when $\mathrm{q}=0$. The condition $\frac{-\pi^{\prime}(0)}{(1-\tau) v_{1}^{\prime}(0)}>\frac{\hat{\pi}(1+\hat{\pi}) p}{(1-p)} E_{k}(g(k))$ is necessary to ensure that at some value of $v_{0}$, the gains from shaping the electorate dominate the social costs of redistribution. The final condition on $g$ ', $(\mathrm{j})$ is a regularity condition needed to avoid perverse results.

Proposition 1 makes several of the key points of the paper. The incumbent pursues more redistribution if more people vote along group lines (base proposition), if 
past choices have little direct effect on voters' preferences (part a), if redistribution entails less waste (part b), and if redistribution has a greater effect on the shape of the electorate (part c). Leaders are less likely to engage in costly redistribution towards their group when their opponent is more likely to come from their own group (part d).

Proposition 1 immediately shows how the Curley effect turns many classic voting results on their heads. Traditionally, economists have argued that governments are more likely to abuse taxes that do not distort behavior. However, when the Curley effect operates, greater distortion encourages socially wasteful redistribution because such distortion is the very mechanism of eliminating politically undesirable voters.

A key feature of our model, which distinguishes it from much of the Public Choice literature, is that leaders derive utility from holding office (they want re-election) but not from governing a richer area. Much of the Public Choice literature (Brennan and Buchanan 1980, Olson 1993) assumes the reverse: leaders care mostly about the size of the government they run, which can be bigger in a richer community. In practice, politicians often care both about the wealth of their community, and the probability of reelection - and this concern will mitigate the Curley effect. However, in many contexts, the benefits of holding office swamp those derivable from a richer community.

In a situation where leaders do care about the wealth of the community, the logic of the Curley effect suggests that they will try to enrich the community while also shaping the electorate. In the urban context, this might mean that they try to create jobs for non-residents, who expand the tax base without being able to vote.

\section{Application to City Politics and Emigration}

Suppose now that the leader is a mayor of a city, that his own group is the Irish, and that the other group is the English (or alternatively have Irish or English ancestors). After the mayor chooses the value of q, both English and Irish voters can move in or out of the city. Over a long enough time horizon, voters move so that their utility levels in 
the city are equal to their utility levels outside the city. We denote the reservation utility of the Irish as $U_{I}\left(N_{I}\right)$ and the reservation utility of the English as $U_{E}\left(N_{E}\right)$, where $N_{I}$ is the number of Irish voters, and $N_{E}$ is the number of English voters. We assume that $U_{I}^{\prime}\left(N_{I}\right)>0$ and $U_{E}^{\prime}\left(N_{E}\right)>0$. These assumptions say that the supply of residents of a given ethnicity is upward sloping: the more Irish voters live in Boston, the more the marginal Irish newcomer must be paid to live in the city.

The final element of the model is the labor market. In our model, the workers and the voters are the same. We assume an aggregate constant returns to scale production function $f\left(N_{I}, N_{E}\right)$. The wage is then equal to $\frac{\partial f\left(N_{I}, N_{E}\right)}{\partial N_{I}}=W_{I}\left(N_{I}, N_{E}\right)$ for the Irish, and $\frac{\partial f\left(N_{I}, N_{E}\right)}{\partial N_{E}}=W_{E}\left(N_{E}, N_{I}\right)$ for the English. The constant returns to scale assumption means that wages for both groups are determined entirely by the ratio of the English to the Irish, which we have denoted by $\pi$. We can then write the wages as $W_{I}(\pi)$, where $W_{I}^{\prime}(\pi) \geq 0$ and $W_{E}(\pi)$ where $W_{E}{ }^{\prime}(\pi) \leq 0$. The wage of each group is assumed to be decreasing in its number, i.e. labor demand curves slope down. We also assume that a positive number of voters from each group always live in the city.

For any value of $\mathrm{q}$, the spatial equilibrium is determined by the two equalities

(6) $W_{I}(\pi)+\tau \pi q=U_{I}\left(N_{I}\right)$, and

(7) $W_{E}(\pi)-q=U_{E}\left(\pi N_{I}\right)$.

We are interested in comparative statics around an equilibrium with no redistribution, so we let $\hat{\pi}$ and $\hat{N}_{I}$ (and $\left.\hat{N}_{E}=\hat{\pi} \hat{N}_{I}\right)$ solve $W_{I}(\hat{\pi})=U_{I}\left(\hat{N}_{I}\right)$ and $W_{E}(\hat{\pi})=U_{E}\left(\hat{\pi} \hat{N}_{I}\right)$. This is the same definition of $\hat{\pi}$ as we had before.

Differentiation of (6) and (7) leads us to our first comparative statics: 
(8) $\frac{\partial \pi}{\partial q}=\frac{\tau \pi^{2} U_{E}^{\prime}\left(N_{E}\right)+U_{I}^{\prime}\left(N_{I}\right)}{U_{I}^{\prime}\left(N_{I}\right)\left(W_{E}^{\prime}(\pi)-N_{I} U_{E}^{\prime}\left(N_{E}\right)\right)-\pi U_{E}^{\prime}\left(N_{E}\right)\left(W_{I}^{\prime}(\pi)+\tau q\right)}$, and

(9) $\frac{\partial N_{I}}{\partial q}=\frac{W_{I}^{\prime}(\pi)+\tau q+\tau \pi W_{E}^{\prime}(\pi)-\tau \pi N_{I} U_{E}^{\prime}\left(N_{E}\right)}{U_{I}^{\prime}\left(N_{I}\right)\left(W_{E}^{\prime}(\pi)-N_{I} U_{E}^{\prime}\left(N_{E}\right)\right)-\pi U_{E}^{\prime}\left(N_{E}\right)\left(W_{I}^{\prime}(\pi)+\tau q\right)}$.

In both equations (8) and (9), the denominator is the same, and it is negative. There are two parts of the denominator. The first part is the effect of an increase in $\pi$ on the utility of the marginal Englishman (which is unambiguously negative), multiplied by the slope of the supply curve of the Irish. The second part is the slope of the supply curve of English (times $\pi$ ) times the impact of an increase in $\pi$ on the utility of the marginal Irishman, which is unambiguously positive. Thus, the overall denominator is negative.

The numerator in equation (8) is the sum of the slopes of the supply curves of both groups. These terms are positive, so expression (8) is negative and the proportion of the English in the electorate falls as the tax rate on them increases.

The numerator in expression (9) cannot be easily signed. There are two positive and two negative terms in it. The first two terms in the numerator are positive: the slope of the Irish wages with respect to the share of English, and $\tau \mathrm{q}$. Because the denominator is negative, these terms represent the negative effect that the transfers can have on the Irish utility. The first term reflects the negative effect of the English mobility on Irish wages; the second term reflects the negative impact of the English exodus on the tax base. The last two terms in the numerator of (9) are both negative. Because the denominator is negative, they both reflect the basic positive effect that redistribution to the Irish has on the Irish utility.

Differentiating (8) leads us to our second proposition. Recall that $v_{0}^{*}$ is the level of the intrinsic ethnic preference for the incumbent above which he wants to redistribute, 
and below which he does not. Thus an increase in $v_{0}^{*}$ means a lower likelihood of redistribution.

Proposition 2: The value of $v_{0}^{*}$ falls as $\tau$ rises.

(a) If we write $W_{I}(\pi)=\widetilde{W}_{I}(\pi)+\omega_{I}(\pi-\hat{\pi})$, then $v_{0}^{*}$ is rising with $\omega_{I}$.

(b) If we write $W_{E}(\pi)=\widetilde{W}_{E}(\pi)-\omega_{E}(\pi-\hat{\pi})$, then $v_{0}^{*}$ is rising with $\omega_{E}$.

(c) If we write $U_{E}\left(N_{E}\right)=\widetilde{U}_{E}\left(N_{E}\right)+\mu_{E}\left(N_{E}-\hat{N}_{E}\right)$, then $v_{0}^{*}$ is rising with $\mu_{E}$ if and only if $\pi W_{I}^{\prime}(\pi)+N_{I} U_{I}^{\prime}\left(N_{I}\right)>-\tau \pi^{2} W_{E}^{\prime}(\pi)$.

(d) If we write $U_{I}\left(N_{I}\right)=\widetilde{U}_{I}\left(N_{I}\right)+\mu_{I}\left(N_{I}-\hat{N}_{I}\right)$, then $v_{0}^{*}$ is rising with $\mu_{I}$ if and only if $\tau \pi\left(N_{I} U_{E}^{\prime}\left(N_{E}\right)-W_{E}^{\prime}(\pi)\right)>W_{I}^{\prime}(\pi)$.

The comparative static on $\tau$ has already been discussed. As redistribution becomes more wasteful, leaders indeed do less of it (near $\mathrm{q}=0$ ). At higher levels of $\mathrm{q}$, this result becomes less clear, because lower values of $\tau$ have the attractive aspect of further repelling the members of the opposing group. Parts (a) and (b) show that higher wage elasticities make redistribution less attractive to the leader. Intuitively, higher wage elasticities mean that redistribution changes wages rather than the voting composition. Since the attractive aspect of redistribution to the leader is its impact of who stays and votes, redistribution that only impacts wages is less desirable.

The intuition on the reservation utility comparative statics in parts (c) and (d) is more complex. Higher values of $\mu_{E}$ and $\mu_{I}$ would seem to make the population less mobile, making redistribution less attractive. There is, however, a countervailing force. One of the factors that keeps the Irish from moving in is that the English are moving out, thereby reducing the Irish wage. If $\pi W_{I}^{\prime}(\pi)+N_{I} U_{I}^{\prime}\left(N_{I}\right)<-\tau \pi^{2} W_{E}^{\prime}(\pi)$, then higher $\mu_{E}$ and the relative immobility of the English mean that the Irish move in relatively more aggressively in response to higher redistribution. Likewise, when $\tau \pi\left(N_{I} U_{E}^{\prime}\left(N_{E}\right)-W_{E}^{\prime}(\pi)\right)<W_{I}^{\prime}(\pi)$, the Irish immobility makes the English more mobile. 
Equation (9) is positive as long as $N_{E} U_{E}^{\prime}\left(N_{E}\right)-\pi W_{E}^{\prime}(\pi)>q+W_{I}^{\prime}(\pi) / \tau$. If redistribution causes the number of the Irish to rise, then the average welfare of the Irish in the city must also rise because $U_{I}^{\prime}\left(N_{I}\right)>0$. We can now determine whether redistribution helps or hurts the Irish voters of the city. This leads us to Proposition 3:

Proposition 3: When $\mathrm{q}=0$, there exists a value of $\tau$, denoted by $\tau^{*}$, which equals $W_{I}^{\prime}(\pi) /\left(N_{E} U_{E}^{\prime}\left(N_{E}\right)-\pi W_{E}^{\prime}(\pi)\right)$, at which higher redistribution neither hurts nor harms the Irish.

(a) For $\tau>\tau^{*}$, the Irish are helped by incremental redistribution and for $\tau<\tau^{*}$ the Irish are hurt by it.

(b) If we write $W_{I}(\pi)=\widetilde{W}_{I}(\pi)+\omega_{I}(\pi-\hat{\pi})$, then $\tau *$ is rising with $\omega_{I}$.

(c) If we write $W_{E}(\pi)=\widetilde{W}_{E}(\pi)-\omega_{E}(\pi-\hat{\pi})$, then $\tau *$ is falling with $\omega_{E}$.

(d) If we write $U_{E}\left(N_{E}\right)=\widetilde{U}_{E}\left(N_{E}\right)+\mu_{E}\left(N_{E}-\hat{N}_{E}\right)$, then $\tau *$ is falling with $\mu_{E}$.

Proposition 3 shows, first, that redistribution can actually harm the Irish. This can occur because the English and the Irish are complements in production. When taxes drive the English out, they can make the Irish worse off. The first, unsurprising, comparative static tells us that this negative effect of taxes is more likely to occur when it entails greater social losses ( $\tau$ is lower). But even when redistribution entails no waste, it can still hurt the Irish because $W_{I}^{\prime}(\pi) /\left(N_{E} U_{E}^{\prime}\left(N_{E}\right)-\pi W_{E}^{\prime}(\pi)\right)$ can be greater than one.

Proposition 3 also shows that the welfare reduction of the favored group is more likely to come about when the decrease in the number of the English has a stronger negative effect on the Irish wages. In addition, the mobility of the English (captured by a low value of $\mu_{E}$ ) also makes redistribution more detrimental to the Irish (because more of the English leave). Finally, a greater elasiticity of the English wage actually leads to smaller losses for the Irish. The reason is that a change in the proportion of the English has a large positive effect on the English wages, which stems their own out-migration. 


\section{Historical Evidence on the Curley Effect}

In this section, we review the cases of two American Mayors, and one of an African President, who practiced Curleyism. Their policies and rhetoric led to emigration and other outcomes consistent with the predictions of the model.

\section{James Michael Curley}

In the case of the Boston Mayor James Michael Curley, the dominant political factors appear to have been his own longevity, the mobility of voters, and Curley's own ethnic appeal. Since policies do not impact migration instantly, longevity is vital, and Curley's political longevity was almost unique. Since the Curley effect for cities operates primarily through migration, massive suburbanization taking place in Boston in the first half of the $20^{\text {th }}$ century, predominantly by Curley's Anglo-Saxon opponents, is central to understanding Curleyism. Finally, as the model makes clear, the incumbent politician must have an innate advantage in appealing to the members of his own group, and Curley was nothing short of remarkable in his ethnic Irish appeal.

James Michael Curley's electoral career spanned 55 years between his first election to the Boston Common Council in 1900 and his final defeat for the Mayoralty in 1955. Curley was first elected to mayor of Boston in 1913. He lost his 1917 run for reelection, but was re-elected three more times over the next 40 years, in 1921, 1929 and 1944. He lost elections for Mayor in 1917, 1937, 1940, 1949 and 1951. Curley was also elected Governor of Massachusetts in 1934, and defeated for that office in 1924 and 1938. He served as a congressman during 1911-1914 and 1943-1946. Curley's access to opportunities to shape the electorate through politics is almost unprecedented.

Over this time period, the composition of Boston's population shifted dramatically. In 1900, Boston was still in part a Yankee city: Curley lost the 1917 to Andrew Peters, a Brahmin candidate. Over the early $20^{\text {th }}$ century, however, many Bostonians migrated to the suburbs, such as Brookline and Newton, powered by the 
streetcar and then the automobile. Boston's small geographic boundaries made this exodus particularly easy. By 1950, the Brahmins had departed. As noted by contemporary observers, "the Yankees have girt their garments well about them, snatched up their skirts, that so much as a hem might not be defiled by contact with 'foreigners,' and have betaken them elsewhere in a spirit little and shallow, if not mean and snobbish." (quoted in Gamm 1999, p.25). The last Brahmin mayor of the City was elected in 1925 (when Curley was precluded by statute from running again).

There could be no Curley effect without Curley's ethnic appeal. In part, Curley's ethnic politics had its roots in the long-standing battles between the English and the Irish. The English discriminated against the Irish, and the Irish resented this discrimination. Curley also came from a poor neighborhood and represented the average Irishman, not the Lace Curtain Irish identifying with the first Irish Mayor of Boston Hugh O'Brien and future President John F. Kennedy. Curley's roots in the city's Irish community gave him a natural identity, and electoral appeal. His large family (seven children), his faithful religious observance (every week at Our Lady of Lourdes), and his home in the Irish area of Jamaica Plain all reinforced his ethnic identity. According to O'Connor "He may have cultivated a rich and mellifluous speaking voice, but none of his followersscrubwomen, teamsters, dockworkers, streetcar conductors, policemen, firemen, housewives — doubted for a minute that 'Jim' was still 'one of us'." Jack Beatty begins his biography of Curley by describing the 100,000 overwhelmingly Irish mourners attending Curley's wake. According to Beatty "For the Irish-Americans among them, especially, he was a political and cultural hero, an axial figure in their annals."

How did Curleyism work? What were the policies that favored the Irish and hurt the English Bostonians, and so encouraged their emigration? There are three main areas where Curley seems to have practiced ethnic favoritism: the distribution of public goods and patronage, financial transfers, and perhaps as importantly his rhetoric.

On the first day of his first administration, Curley announced what may have been his boldest scheme for massive redistribution from the Protestant Boston to his Irish 
supporters: his plan to sell the Boston Garden and use the proceeds to build parks in the neighborhoods of the city. This proposal "sent Yankees into fits of apoplexy" (O'Connor, p. 187). It was shelved, but was eventually followed by decades of favoritism in the allocation of public buildings:

While Curley built playgrounds in Dorchester and Roxbury [Irish Wards], he let Scollay Square become a place where ugly tattoo parlors and sleazy burlesque houses blighted the historic landscape. While he planned extensive bathhouses in South Boston, the docks and piers along Atlantic Avenue rotted on the pilings. While he laid out miles of paved sidewalks in Charlestown and East Boston, the cobblestones of Beacon Hill fell apart and the old lampposts came tumbling down (O'Connor, p. 206).

In his first administration "Curley cited as his greatest accomplishments the beginnings of an $\$ 11$ million expansion of the Boston City Hospital and of the Strandway, a beach-lined motor parkway set along the Dorchester Bay side of the South Boston peninsula." These were vast projects which not only employed hundreds, if not thousands, of Curley supporters but also delivered public services disproportionately to Curley's Irish base: "Curley produced numerous social, medical and recreational facilities for his low-income supporters in the neighborhoods that fringed the downtown area." Such projects would continue throughout his terms.

Curley's building was one means of redistributing from the English to the Irish, but he also engaged in more direct financial transfers. Curley's preferred form of redistribution was public employment (generally at above market wages), not welfare, and he made sure that this public employment went overwhelmingly to his Irish (and other ethnic) supporters not to his Protestant enemies. In his autobiography, he details a "reform" (Protestant) member of the City Council who offered to be City Treasurer and to donate the bulk of the salary to a charity of Curley's choosing. Curley told him that he would only get the job if "he could find in the city records a single instance wherein any Irish Catholic ever received a city appointment to any position higher than policeman until Hugh O'Brien was elected Mayor in 1885." 
In Curley's first year as mayor, he raised spending considerably and "raised the salaries of lower-paid workers." "Curley cut the pay of the higher officers of the police and fire departments, but approved raises for police patrolmen and privates. He cut the salaries of school doctors, but not of school custodians" (Beatty, p. 138). Patronage and public projects were the tangible tools of redistribution in Boston.

Still, Curley's unending rhetorical war on the Anglo-Saxons, his histrionic ethnic baiting, may have been the hallmark of his mayoralty. Curley accused the English of having a temperament inclined towards "political chicanery and hypocricy," and railed against "the inhumane numb-skulduggery of the Yankee overlords." "The day of the Puritan has passed, the Anglo-Saxon is a joke, a newer and better America is here," he said, and "the New England of the Puritans and the Boston of rum, codfish and slaves are as dead as Julius Caeser' (quoted in O'Connor, p. 188). Instead, he favored a Boston filled with " a virile, intelligent, God-fearing, patriotic people like the Irish." Such rhetoric should perhaps be viewed not only as evidence of intent to favor one's own community, but also as a form of redistribution given its likely impact on both the Irish and the English voters.

Boston did not thrive during the Curley era. Between 1910 and 1950, it had the lowest population growth rate of any city in the U.S. with population over 300,000 in 1910. Boston's population rose by only $19.5 \%$ in this period, compared to $39.3 \%$ for Massachusetts, and $63.9 \%$ for the U.S. as a whole. The relative wealth of the city also fell. Were Boston's Irish hurt as well? This is harder to answer. One clue is that the overall Irish population also rose by only a small amount over this time period. Beatty (1992) recognizes that "many [Irish] Bostonians were worse off in 1950 than they or their families had been 1914, and Curley was the major reason why" (p. 501). He notes that many of the public sector opportunities created by Curley came at the expense of other, private sector opportunities, but does not reach a final quantitative judgment. 


\section{Coleman Young}

Coleman Young was elected the first black Mayor of Detroit in 1973 in a four percentage point victory over John Nichols, the white police commissioner. The election split along racial lines. Every white precinct and over 90 percent of the white vote favored Nichols. Every black precinct and over 90 percent of the black vote favored Young. Detroit's long tradition of institutionalized racism and racial hostility exploded in the 1967 riot, among the deadliest and most destructive in U.S. history (Sugrue 1994). Six years later, Young was able to mobilize black voters and become Mayor.

Between 1970 and 1990, the share of blacks in Detroit's population grew from 43.7 to 75.7 percent. Young's electoral strength expanded as well. In no subsequent election was Young's margin of victory as small as in 1973. In 1977, Young beat Ernest Browne, a moderate black candidate whom he described as "the great black white hope," by 18 percentage points. In 1983, Young beat his last white opponent by 32 percentage points. In his final two elections, Young defeated a black opponent, Tom Barrow, by 20 percentage points in 1985 and 12 percentage points in 1989.

Unlike Curley, Young always claimed to support integration. The closest he got to asking whites to leave was in his inaugural address, when he urged thuggish policemen (overwhelmingly white in his view) to "hit the road." Still, according to L. Brooks Patterson, a former Oakland County prosecutor, "Coleman Young has made it very clear that the honkies are not welcome. ... When he vacates his throne ... you'll find a warming." Jacoby (1988) writes that Young "encouraged the black city to cut itself off." She cites observers such as Detroit News columnists Pete Waldmeir writing that Young "was trying to drive whites out and he cut their services," and Irene McCabe saying that Young "wanted everything black and treated whites as second-class citizens."

We cannot be sure that Young's actions were strategically designed to drive the whites out. Suburbanization, the decline in the automobile industry, and racist hostility to Young were also important factors. But it is hard to ignore the impact of Young's 20-year 
rule. Whites didn't just suburbanize - they moved directly outside of Detroit's city limits (Glaeser, Kahn and Rappaport, 2000). They weren't just moving to lower density suburbs, they were specifically escaping Young's regime. A 1980 poll showed that 70 percent of Detroit's whites agreed with the sentence "Ever since blacks became the majority in Detroit white people are often discriminated against here." Young's policies created an overwhelmingly black city that overwhelmingly supported him.

Young's racial favoritism can be seen in his tax policy and his distribution of city services. A 1982 referendum tripled the commuter tax from .5 percent to 1.5 percent, and raised the residents' income tax rate from 2 to 3 percent. This tax, which had no impact on Young's poorer black supporters, strengthened the incentive for the better off to leave Detroit. City governments rarely pass income taxes, presumably because of the adverse migration effects. Young eagerly sought to tax his richer constituents to fund redistribution, arguably to drive them out.

Young initiated large building projects that put his supporters on the payroll. $\mathrm{He}$ lobbied for federally supported public housing - an absurdity in a city with huge amounts of housing selling for less than new construction costs (Glaeser and Gyourko, 2002) - to keep his supporters, as opposed to whites, as city residents. At the same time, Young cut back on the basic services that white Detroiters valued, such as police and fire. In 1976, he cut the police force by 20 percent, which along with his other attacks on the police department, perpetrated lawlessness in Detroit. Trash collection declined by 50 percent during Young's early years.

Young's other strategies also followed closely the logic of the Curley effect. Young tried to generate jobs and tax revenues without residents. The most obvious example of this is Young's continuing but unsuccessful attempts to bring a Casino to Detroit. Gambling would create revenues, but also repel middle class voters. It was a perfect strategy for a mayor who wanted to raise income and tax revenues without attracting voters. Young also strongly supported Henry Ford II's Renaissance Center, a 
business complex that would generate tax revenues while keeping white voters in the suburbs. Young's other construction projects had a similar flavor of Curleyism.

Did Young hurt Detroit? Did he hurt the black residents of Detroit? There is no question that Detroit was in much worse shape when Young left office than when he first entered it. Its population fell from 1.51 million in 1970 to 1.03 million in 1990 , a 32 percent decline. The unemployment rate as a percentage of civilian labor force rose from $10.3 \%$ in 1969 to $20.6 \%$ in 1990 . The percentage of households living below the poverty line rose from $18.6 \%$ to $29.8 \%$. Nearly all the victims of this unemployment and poverty were Young's black supporters. Over Young's twenty years, surely in part due to his policies, Detroit became an overwhelmingly black city mired in poverty and social problems. While some of black Detroit was worse off before Young, it is hard to believe that a less confrontational mayor would not have helped his constituency more.

\section{Robert Mugabe}

Post-independence African leaders who saw the whites as their political opponents often took concrete steps to encourage white emigration. Zimbabwe's Robert Mugabe clearly understood the workings of the Curley Effect, and like Curley spoke openly about his desire for white emigration. In 1985, Mugabe said:

Those whites who have not accepted the reality of a political order in which the Africans set the pace will have to leave the country. We are working with those whites who want to work with us. But the rest will have to find a new home. (Meredith, 2002, p. 56).

Mugabe recognized whites as his opponents and took steps calculated to get them to migrate out. Because whites had human and physical capital vital to the functioning of the economy, their exodus — encouraged by Mugabe-impoverished Zimbabwe.

Immediately after his first election, Mugabe actually reached out to whites. He claimed that he wanted to draw a "line in the past" and get over the 20 years of revolution 
that had wrecked Ian Smith's Rhodesia. According to Meredith (2002), many white farmers favored Mugabe's election because they thought it would bring peace. For a while Mugabe did treat the small group of elite white farmers well, recognizing their economic importance and making sure that they did not fear expropriation. The whites were responsible for the bulk of Zimbabwe's exports. Good treatment of the minority whites was also vital for foreign aid.

But when in 1981 a bomb exploded in his party's headquarters, Mugabe thought (probably correctly) that dissident whites were responsible. He responded by announcing that "my government is bound to revise its policy of national reconciliation and take definite steps to mete out harsh punishment to this clan of unrepentant and criminal savages" (Meredith, 2002, p. 52), and then harassing and imprisoning white leaders. After whites opposed Mugabe in the 1985 elections, he undertook a more widespread policy of attacking white farmers. He did not apparently mind the economic costs and urged his opponents to "take their money and fly away" (Meredith, 2002, p. 129).

Yet the most egregious Curleyist policies followed Mugabe's loss in a referendum in 2000. His control over the country was being challenged by the Movement for Democratic Change (MDC), launched in 1999. MDC had black leadership and represented trade unions, student groups and human rights organizations. It was by no means a white organization, although the whites supported it. In 2000, to counter the MDC's calls for constitutional change, Mugabe presented his own new draft constitution. It supported the status quo except for inserting a clause that obligated Britain to pay for any land that Mugabe decided to expropriate. Mugabe presented this draft constitution for a referendum and for the first time, he was soundly defeated.

In response to this political threat, Mugabe stepped up his actions against whites. He initiated a series of "invasions," in which 1,500 white farms were seized by marauders whom Mugabe claimed to be independent. "It soon became evident not only that the invaders were being paid but that prominent Zanu-PF [Mugabe's party] officials, army officers, CIO agents, and even police officers were actively involved in directing events" 
(Meredith, 2002, p. 169). According to Didymus Mutasa, a Mugabe loyalist "The whites have themselves to blame because they shot themselves in the foot by mobilizing people to throw away the draft constitution" (Meredith, 2002, p. 169). Mugabe ultimately acknowledged the political roots of the invasions, and said that the whites "mobilizing, actually coercing, their labour force on the farms to support the one position opposed to government, has exposed them as not our friends, but enemies."

Farm invasions were not garden variety redistribution. They did not create much wealth, if any, for Mugabe's supporters. They were only a means of attacking Mugabe's political enemies. As the Catholic Bishop of Bulawayo said, "the government and ZanuPF had twenty years to solve the land question and they still had no plan and no commission to tackle the land issue." The goal of the invasions was not to redistribute but rather to "revenge against the 'No' vote during the constitutional referendum in February and to make sure that Zanu-PF remains in power indefinitely." (Meredith, 2002, p.185). All that mattered was pain for the whites, no matter what the waste.

But was Mugabe actually encouraging emigration? For the Curley Effect to operate, the incumbent's harmful actions must shape the electorate. It is a matter of fact that thousands of whites fled Zimbabwe after the invasions, as Mugabe announced: "Britain says it will take 20,000 people. They are free to go. We can even assist them by showing them the exit" (Meredith, 2002, p. 180). Mugabe's policies encouraged the emigration not only of whites, but also of skilled blacks who opposed his regime.

Twenty years after Mugabe took over, Zimbabwe descended into a mire of poverty, corruption and anarchy. Mugabe himself did not appear to care for wealth, but he did single-mindedly pursue power and office. To that aim, his policies induced the whites, and others with skills and capital, to flee. He pursued these policies knowing, and encouraging, the emigration that would follow. Meredith (2002) concludes his book on Mugabe by writing: "But there was a crude logic to Mugabe's actions. His sole purpose 
had become to hold on to power. Whatever the cost, his regime was dedicated towards that end. Violence had paid off in the past; he expected it to secure the future"4.

\section{Education and Occupational Choice}

In this model, we focus on policies dividing voters into social classes. We call the two classes managers (which includes entrepreneurs, professionals, etc.) and workers. A production function determines the wages of the two groups. The total population is fixed, so $N_{M}+N_{L}=\bar{N}$ and we can write everything as a function of $\pi$, the ratio of managers to workers. The workers can become managers only if they make a human capital investment costing $C\left(N_{M}\right)$, which is rising in the number of people who try to become managers. In this case, so we can use the notation $C\left(N_{m}\right)=C(\pi \bar{N} /(1+\pi))=c(\pi)$. This cost reflects the potential barriers to mobility.

The leader can redistribute among the two groups. Denote taxes on each manager by q, so each worker benefits by $\tau \frac{N_{M}}{N_{L}} q$, or $\tau \pi q$. Since all people are equally talented in all jobs, the number of managers and workers is determined by the equality of returns:

$$
W_{M}(\pi)-q-c(\pi)=W_{L}(\pi)+\tau \pi q
$$

Let $\hat{\pi}$ solve $W_{M}(\hat{\pi})-c(\hat{\pi})=W_{L}(\hat{\pi})$-- the equilibrium with no redistribution. To solve for the impact of increases in q on $\pi$, we differentiate (10) to find:

(11) $\frac{\partial \pi}{\partial q}=-\frac{1+\tau \pi}{c^{\prime}(\pi)+W_{L}^{\prime}(\pi)-W_{M}^{\prime}(\pi)+\tau q}$,

\footnotetext{
${ }^{4}$ One can also see a (milder) Curley effect operating in Canada in the form of the policies pursued by Partie Quebecois in gallicizing Quebec, such as discouraging the use of English. These policies drove Anglophones from Quebec, raised the electoral prowess of Partie Quebecois, and impoverished the province relative to the rest of Canada.
} 
which is unambiguously negative.

We use this derivative to obtain the counterpart of Proposition 2 for this model:

Proposition 4: The value of $v_{0}^{*}$ is falling with $\tau$.

(a) If we write $c(\pi)=\widetilde{c}(\pi)+\kappa(\pi-\hat{\pi})$, then the value of $v_{0}^{*}$ is rising with $\kappa$.

(b) If we write $W_{L}(\pi)=\widetilde{W}_{L}(\pi)+\omega_{L}(\pi-\hat{\pi})$, then the value of $v_{0}^{*}$ is rising with $\omega_{L}$

(c) If we write $W_{M}(\pi)=\widetilde{W}_{M}(\pi)-\omega_{M}(\pi-\hat{\pi})$, then the value of $v_{0}^{*}$ is rising with $\omega_{M}$.

The intuition of Proposition 4 is similar to our earlier logic. Increases in any of the elasticities reduce the extent to which rises in $\mathrm{q}$ alter the composition of the electorate. When wages adjust sharply to changes in the composition of the electorate, the electorate change is likely to be smaller (parts $b$ and $c$ ). Likewise, when the cost of education rises sharply with the number of managers, the impact of an increase in q on the number of managers is smaller, making the Curley effect less likely to materialize (part a).

Finally, we turn to the impact of redistribution on the welfare of the workers. Increases in q reduce the welfare of the workers if:

$$
\tau \pi\left(c^{\prime}(\pi)-W_{M}^{\prime}(\pi)\right)<W_{L}^{\prime}(\pi)+\tau q
$$

This leads us to Proposition 5, which is the counterpart of Proposition 3 for this model:

Proposition 5: When $\mathrm{q}=0$, there exists a value of $\tau$, denoted by $\tau$, which equals $W_{L}^{\prime}(\hat{\pi}) / \hat{\pi}\left(c^{\prime}(\hat{\pi})-W_{M}^{\prime}(\hat{\pi})\right)$, and at which increases in the level of redistribution neither hurt nor harm the workers. 
(a) For $\tau>\tau^{*}$, the workers are helped by redistribution and for $\tau<\tau *$, they are hurt.

(b) If we write $W_{L}(\pi)=\widetilde{W}_{L}(\pi)+\omega_{L}(\pi-\hat{\pi})$, then $\tau *$ is rising with $\omega_{L}$.

(c) If we write $W_{M}(\pi)=\widetilde{W}_{M}(\pi)-\omega_{M}(\pi-\hat{\pi})$, then $\tau *$ is falling with $\omega_{M}$.

(d) If we write $c(\pi)=\widetilde{c}(\pi)+\kappa(\pi-\hat{\pi})$, then $\tau *$ is falling with $\kappa$.

Proposition 5 makes many of the same points as Proposition 3 but in the occupational choice context. Increases in transfers can either help or hurt the workers. If becoming a manager has a fixed cost (i.e., $c(\pi)=c$ ), then transfers help workers if and only if $\left.\tau>-W_{L}^{\prime}(\hat{\pi}) / \hat{\pi} W_{M}^{\prime}(\hat{\pi})\right)>1$. With a less elastic supply of managers, it becomes more likely that transfers help the workers. As before, increases in the elasticity of workers' wages with respect to the number of managers tend to increase the extent to which favoring workers only hurts them.

Some of the variables that make redistribution more likely also make it more costly. For example, when the supply of managers is highly elastic (i.e. $\kappa$ is low), the likelihood of using redistribution is higher, as is its destructive impact on worker welfare. This is one of the pernicious features of the Curley effect: redistribution is often more likely to be used when its social costs are greater.

\section{The British Labour Party}

Before Thatcher, party loyalties in Britain were shaped by "class" identity. Working class individuals - generally defined as manual laborers - overwhelmingly voted Labour. In ten out of the eleven general elections between 1963 and 1992, the share of manual workers voting Conservative was below 35.5 percent (Crewe, Fox and Day, 1995). In the 1960s, Labour's share of these workers' votes was around 2/3. Labour's share of trade union members' votes is similar during this period: about one in five trade union members voted conservative. Goldthorpe et al. (1968) report samples of working class respondents where 80 percent vote Labour and 13 percent vote Conservative. Conversely, non-manual laborers tended to vote Conservative. Between 
1963 and 1992, the proportion of professionals and managers that voted labor was always below 24 percent. The minimum proportion of these non-manual workers that voted Conservative was 52 percent.

Numerous observers have argued that British politics are dominated by class loyalty. Butler and Stokes (1974) write: "class has long been pre-eminent among the factors used to explain party allegiance in Britain — and not just by academic observers ... partisanship has followed class lines more strongly in Britain than anywhere else in the English speaking world." Goldthorpe et al. (1968) establish that their surveyed "affluent" members of the working class "have a relatively high and stable Labour vote" because of "the perception of the Labour Party as the party of the 'working man' or of the 'working class." As one of their respondents noted, "I consider myself a working man, so a working man should always vote for Labour."

The logic of the Curley effect suggests that the Labour party should have been trying to enlarge the working class, or at least to stem the exodus from it. "[Labour's] class appeal is being undermined, because the working class itself, even the lower categories within it, is emerging from its earlier unhappy plight; manual workers are gradually moving over into the white-collar category, which does not identify itself with the unskilled or semi-skilled labourers; and many, particularly among the young, are now crossing the class frontiers into the middle class" (Abrams and Rose 1960, p. 119). Cannadine (1999) writes that Labour feared what English sociologists call "working-class embourgeoisement," a phenomenon that "was regularly invoked throughout the decade of the 1950s to explain what then seemed to be the secular decline of the Labour Party as a political force" (Goldthorpe et al., 1968).

To address this concern, the post-war (pre-Tony Blair) Labour Prime Ministers, Clement Attlee, Harold Wilson and James Callaghan, all engaged in some form of class warfare. In the language of our model, they all increased the level of "q". "Attlee's government, by raising taxation, nationalizing industries, setting up the welfare state, and reducing the delaying powers of the house of lords, attacked aristocrats, the rich, bankers, doctors, newspaper owners, and shareholders, and these measure were accompanied by 
extravagantly denunciatory language from ministers such as Bevan, Shinwell and Dalton" (Cannadine 1999). The tax rates, in particular, were not just punitive on the rich (76 percent marginal rate on people earning more than 20,000 pounds per year), but high on almost everyone (50 percent marginal rate on people earning between 5,000 and 10,000 pounds annually). Later cabinets increased these rates further. Under Wilson, the top marginal rate rose to 83 percent (Annual Abstract of Statistics, 1952 and 1972). These rates eliminated almost all of the wage gains that would accrue from undertaking a costly transition out of the working class.

A second major Labour policy was nationalization. Attlee nationalized several of Britain's largest industries: coal mining, civil aviation, and transport. These were highly unionized, declining industries, which would have lost employment rapidly in the absence of public ownership. Through public ownership, the Labour party ensured that a large sector of the economy kept its employment up and its employees in the working class and in unions. Thus 36 percent of the British labor force was unionized in 1945, and 60 percent in 1979 (Annual Abstract of Statistics 1952 and 1982). During this time period, the American unionization rate declined from 25 percent to 21 percent (Statistical Abstract of the US 1982). Much of the growth of British unions can be directly tied to the high unionization rate of the public sector and the large growth in that sector, itself the result of Labour's nationalization policies in the declining industries.

Finally, in its education policy, Britain under Labour kept a much earlier schoolleaving age than did the United States. According to one early statement: "We must use the formative years of adolescence in order to make the workers, when they come to manhood or womanhood, at once better citizens and better Trade Unionists." (Trade Union Congress Annual Report, 1922, quoted in Barker, 1972). Barker also discusses Labour leaders who "did not want to support an educational scheme which would lead a man 'to come along and patronize us."”

Did Labour's policies hurt Britain and its working class? Britain had clearly declined relative to any reasonable comparison group between 1945 and 1979. In 1945, it was richer than France, Germany, and Italy. By 1979, it was much poorer than any of 
them. While we cannot attribute Britain's relative collapse over this time period to the Curley effect with confidence, Labour's policies succeeded at keeping the size of the working class up and simultaneously reducing entrepreneurship and growth in Britain.

\section{Conclusion.}

In this paper, we have shown how differential taxes on groups of voters, such as ethnic groups or social classes, can shape the electorate. We argued that some political leaders use such taxes to increase the likelihood of re-election by encouraging emigration of voters opposing them, or stopping social mobility of their supporters. Moreover, these taxes can be attractive to a political leader even if the consequence is the impoverishment of both the overall community and their own supporters. We called such policies the Curley effect, and claimed that they describe the tactics of numerous politicians, including American mayors James Curley and Coleman Young, Zimbabwe's President Robert Mugabe, as well as of the Labour Party in Britain prior to the Thatcher era.

Our theoretical models, as well as empirical examples, all share a central conceptual theme. Specifically, it is generally thought in economics, following the fundamental research of Tiebout (1956) and Brennan and Buchanan (1980), that elastic response by the voters to tax and other policies disciplines the government. Good policies bring in resources and voters; bad ones keep them out. With the Curley effect, this result is reversed. When politicians seeking to stay in power use distortionary policies to force out their political opponents, the more elastic response renders bad policies more rather than less attractive. The Curley effect, and more generally the economics of shaping the electorate, might thus shed light on a broad range of government policies that appear too bad to be true from alternative perspectives. 


\section{Appendix: Proofs of Propositions}

Proof of Proposition 1: Define

$$
h\left(v_{0}\right)=\frac{-\pi^{\prime}(0)}{\hat{\pi}(1+\hat{\pi})} E_{k}\left(G\left(v_{0}-k\right)-G\left(-v_{0}-k\right)\right)-v_{1}^{\prime}(0) E_{k}\left(g\left(k-v_{0}\right)-\tau g\left(v_{0}+k\right)+\frac{(1-\tau) p g(k)}{(1-p)}\right)
$$

When $v_{0}$ equals $0, h\left(v_{0}\right)=-p v_{1}^{\prime}(0)(1-\tau) E_{k}(g(k)) /(1-p)<0$.

As $v_{0}$ goes to infinity, $h\left(v_{0}\right)$ goes to $\frac{-\pi^{\prime}(0)}{\hat{\pi}(1+\hat{\pi})}-v_{1}^{\prime}(0) \frac{(1-\tau) p}{(1-p)} E_{k}(g(k))$, because $\mathrm{g}(\mathrm{k})$ goes to zero as $\mathrm{k}$ goes to infinity. If $\frac{-\pi^{\prime}(0)}{(1-\tau) v_{1}^{\prime}(0)}>\frac{\hat{\pi}(1+\hat{\pi}) p}{(1-p)} E_{k}(g(k))$, this limit is positive.

Differentiation gives us that:

(*) $h^{\prime}\left(v_{0}\right)=\frac{-\pi^{\prime}(0)}{\hat{\pi}(1+\hat{\pi})} E_{k}\left(g\left(v_{0}-k\right)+g\left(v_{0}+k\right)\right)+v_{1}^{\prime}(0) E_{k}\left(g^{\prime}\left(k-v_{0}\right)-\tau g^{\prime}\left(k+v_{0}\right)\right)$

The first component of this expression is positive. Since symmetry implies that $\mathrm{g}^{\prime}(\mathrm{x})=-$ $g^{\prime}(-x)$, we note that

$$
\begin{aligned}
& E_{k}\left(g^{\prime}\left(k-v_{0}\right)+g^{\prime}\left(k+v_{0}\right)\right)=\int_{k>0}\left(g^{\prime}\left(k-v_{0}\right)+g^{\prime}\left(k+v_{0}\right)\right) f(k) d k+\int_{k<0}\left(g^{\prime}\left(k-v_{0}\right)+g^{\prime}\left(k+v_{0}\right)\right) f(k) d k= \\
& \int_{k>0}\left(g^{\prime}\left(k-v_{0}\right)+g^{\prime}\left(k+v_{0}\right)\right) f(k) d k+\int_{k>0}\left(g^{\prime}\left(-k-v_{0}\right)+g^{\prime}\left(-k+v_{0}\right)\right) f(k) d k= \\
& \int_{k<0}\left(g^{\prime}\left(k-v_{0}\right)+g^{\prime}\left(k+v_{0}\right)\right) f(k) d k-\int_{k>0}\left(g^{\prime}\left(k+v_{0}\right)+g^{\prime}\left(k-v_{0}\right)\right) f(k) d k=0
\end{aligned}
$$

and we can rewrite $(*)$ as

$$
h^{\prime}\left(v_{0}\right)=\frac{-\pi^{\prime}(0)}{\hat{\pi}(1+\hat{\pi})} E_{k}\left(g\left(v_{0}-k\right)+g\left(v_{0}+k\right)\right)-(1-\tau) v_{1}^{\prime}(0) E_{k}\left(g^{\prime}\left(k+v_{0}\right)\right)
$$

As $g^{\prime}(0)=0$, and $g^{\prime}(k)$ goes to zero as $k$ goes to infinity and $g^{\prime}(k)<0$ for all positive $k$ (from single-peakedness), it must the case that there is some $\mathrm{k}$ between zero and infinity where $\mathrm{g}$ ' $(\mathrm{k})=0$. We denote this $\mathrm{k}$ by $\mathrm{k}^{*}$.

We also use the Taylor series approximations for $g^{\prime}(k+x)$ of $g^{\prime}(k)+g^{\prime \prime}(k) x$ and $\mathrm{g}^{\prime \prime}(\mathrm{k})=\mathrm{g}{ }^{\prime}\left(\mathrm{k}^{*}\right)+\left(\mathrm{k}-\mathrm{k}^{*}\right) \mathrm{g},{ }^{\prime}\left(\mathrm{k}^{*}\right)$. 


$$
\begin{aligned}
& E_{k}\left(g^{\prime}\left(k+v_{0}\right)=\int_{k>0}\left(g^{\prime}\left(k+v_{0}\right)\right) f(k) d k+\int_{k<0}\left(g^{\prime}\left(k+v_{0}\right)\right) f(k) d k=\right. \\
& \int_{k>0}\left(g^{\prime}\left(k+v_{0}\right)\right) f(k) d k+\int_{k>0}\left(g^{\prime}\left(-k+v_{0}\right)\right) f(k) d k= \\
& \left.\int_{k>0}\left(g^{\prime}\left(k+v_{0}\right)-g^{\prime}\left(k-v_{0}\right)\right) f(k) d k \approx 2 v_{0} \int_{k>0} g^{\prime \prime}(k) f(k) d k \approx 2 v_{0} g^{\prime \prime \prime}\left(k^{*}\right) \int_{k>0}\left(k-k^{*}\right)\right) f(k) d k
\end{aligned}
$$

If terms involving g',' $\left(\mathrm{k}^{*}\right)$ and higher order terms are small, they can be ignored and $h^{\prime}\left(v_{0}\right)>0$. Combining the facts that $h(0)<0, h^{\prime}\left(v_{0}\right)>0$ and $h\left(v_{0}\right)>0$ for a large enough value of $v_{0}$ guarantees us that there exists a unique value of $v_{0}$ at which $h\left(v_{0}\right)=0$. We denote that value by $v_{0} *$.

If we use the notation $h\left(v_{0} *, x\right)=0$ for any other parameter $\mathrm{x}$, then differentiation tells us that $\frac{\partial v_{0}^{*}}{\partial x}=-\frac{\partial h\left(v_{0}^{*}, x\right)}{\partial x} / \frac{\partial h\left(v_{0}^{*}, x\right)}{\partial v_{0}^{*}}$. Since $h^{\prime}\left(v_{0}\right)>0$, the sign of $\frac{\partial v_{0}^{*}}{\partial x}$ must be the opposite of $\frac{\partial h\left(v_{0}^{*}, x\right)}{\partial x}$. If $v_{1}(x)=\widetilde{v}_{1}(x)+v x$, then $\frac{\partial h\left(v_{0}^{*}, v\right)}{\partial v}$ equals $E_{k}\left(g\left(k-v_{0}^{*}\right)-\tau g\left(v_{0}^{*}+k\right)+\frac{(1-\tau) p g(k)}{(1-p)}\right)$, which must be negative since $\frac{-\pi^{\prime}(0)}{\tilde{\pi}(1+\tilde{\pi})} E_{k}\left(G\left(v_{0}-k\right)-G\left(-v_{0}-k\right)\right)$ is positive.

Differentiating with respect to $\tau$ yields: $\frac{\partial h}{\partial \tau}=\frac{-\frac{\partial \pi^{\prime}(0)}{\partial \tau}}{\hat{\pi}(1+\hat{\pi})} E_{k}\left(G\left(v_{0}-k\right)-G\left(-v_{0}-k\right)\right)+v_{1}^{\prime}(0) E_{k}\left(g\left(k+v_{0}\right)+\frac{p g(k)}{1-p}\right), \quad$ which $\quad$ is positive as long as $\frac{\partial \pi^{\prime}(0)}{\partial \tau} \leq 0$.

$$
\text { If } \pi(q)=\tilde{\pi}(q)-\pi_{0} q \text {, then } \frac{\partial h\left(v_{0}^{*}, x\right)}{\partial \pi_{0}} \text { equals } \frac{E_{k}\left(G\left(v_{0}-k\right)-G\left(-v_{0}-k\right)\right)}{\hat{\pi}(1+\hat{\pi})} \text {, which }
$$

is positive. Moreover, any other variable that increases $\pi^{\prime}(0)$ has a negative effect on $h\left(v_{0}^{*}, x\right)$ and any other variable that decreases $\pi^{\prime}(0)$ has a positive impact on $h\left(v_{0}^{*}, x\right)$.

Finally, $\frac{\partial h\left(v_{0}^{*}, x\right)}{\partial p}$ equals $\frac{-v_{1}^{\prime}(0)(1-\tau)}{(1-p)^{2}} E_{k}(g(k))$ which is negative. 
Proof of Proposition 2: Differentiation tells us that $\frac{\partial \pi^{\prime}(0)}{\partial \tau}$ equals $\frac{\pi^{2} U_{E}^{\prime}\left(N_{E}\right)}{U_{I}^{\prime}\left(N_{I}\right)\left(W_{E}^{\prime}(\pi)-N_{I} U_{E}^{\prime}\left(N_{E}\right)\right)-\pi U_{E}^{\prime}\left(N_{E}\right) W_{I}^{\prime}(\pi)}$ which is clearly negative and satisfies the condition in Proposition 1, Part (b). It is clear that $\omega_{I}, \omega_{E}, \mu_{E}$ and $\mu_{I}$ do not change the equilibrium level of $\tilde{\pi}$. Differentiation then yields:

$$
\begin{aligned}
& \frac{\partial \pi^{\prime}(0)}{\partial \omega_{I}}=\frac{\left(\tau \pi^{2} U_{E}^{\prime}\left(N_{E}\right)+U_{I}^{\prime}\left(N_{I}\right)\right) \pi U_{E}^{\prime}\left(N_{E}\right)}{\left(U_{I}^{\prime}\left(N_{I}\right)\left(W_{E}^{\prime}(\pi)-N_{I} U_{E}^{\prime}\left(N_{E}\right)\right)-\pi U_{E}^{\prime}\left(N_{E}\right) W_{I}^{\prime}(\pi)\right)^{2}}>0, \text { and } \\
& \frac{\partial \pi^{\prime}(0)}{\partial \omega_{E}}=\frac{\left(\tau \pi^{2} U_{E}^{\prime}\left(N_{E}\right)+U_{I}^{\prime}\left(N_{I}\right)\right) U_{I}^{\prime}\left(N_{I}\right)}{\left(U_{I}^{\prime}\left(N_{I}\right)\left(W_{E}^{\prime}(\pi)-N_{I} U_{E}^{\prime}\left(N_{E}\right)\right)-\pi U_{E}^{\prime}\left(N_{E}\right) W_{I}^{\prime}(\pi)\right)^{2}}>0
\end{aligned}
$$

Then $\frac{\partial \pi^{\prime}(0)}{\partial \mu_{E}}=\frac{\left(\pi W_{I}^{\prime}(\pi)+N_{I} U_{I}^{\prime}\left(N_{I}\right)+\tau \pi^{2} W_{E}^{\prime}(\pi)\right) U_{I}^{\prime}\left(N_{I}\right)}{\left(U_{I}^{\prime}\left(N_{I}\right)\left(W_{E}^{\prime}(\pi)-N_{I} U_{E}^{\prime}\left(N_{E}\right)\right)-\pi U_{E}^{\prime}\left(N_{E}\right) W_{I}^{\prime}(\pi)\right)^{2}}$, which is positive if and only if $\pi W_{I}^{\prime}(\pi)+N_{I} U_{I}^{\prime}\left(N_{I}\right)>-\tau \pi^{2} W_{E}^{\prime}(\pi)$

Finally,

$$
\frac{\partial \pi^{\prime}(0)}{\partial \mu_{I}}=\frac{\left(-\tau \pi W_{E}^{\prime}(\pi)+\tau \pi N_{I} U_{E}^{\prime}\left(N_{E}\right)-W_{I}^{\prime}(\pi)\right) \pi U_{E}^{\prime}\left(N_{E}\right)}{\left(U_{I}^{\prime}\left(N_{I}\right)\left(W_{E}^{\prime}(\pi)-N_{I} U_{E}^{\prime}\left(N_{E}\right)\right)-\pi U_{E}^{\prime}\left(N_{E}\right)\left(W_{I}^{\prime}(\pi)+\tau q\right)\right)^{2}},
$$

which is positive if and only if $\tau \pi\left(N_{I} U_{E}^{\prime}\left(N_{E}\right)-W_{E}^{\prime}(\pi)\right)>W_{I}^{\prime}(\pi)$

Proof of Proposition 3: Redistribution increases the number of Irish if and only if $h(\tau)=N_{E} U_{E}^{\prime}\left(N_{E}\right)-\pi W_{E}^{\prime}(\pi)-W_{I}^{\prime}(\pi) / \tau>0$. If the number of Irish rises, then $U_{I}\left(N_{I}\right)$ rises, which implies that $W_{I}(\pi)+\tau \pi q$ must increase as well. If the number of Irish decreases, then $W_{I}(\pi)+\tau \pi q$ must fall. At $\mathrm{q}=0$, the values of $\pi$ and $N_{E}$ are independent of $\tau$. When $\tau$ equals $W_{I}^{\prime}(\pi) /\left(N_{E} U_{E}^{\prime}\left(N_{E}\right)-\pi W_{E}^{\prime}(\pi)\right)$ (a positive number), then $h(\tau)=0$, and the rest of the proposition follows from $h^{\prime}(\tau)=W_{I}^{\prime}(\pi) / \tau^{2}>0$.

The value of $\tau^{*}$ satisfies $\tau^{*}=W_{I}^{\prime}(\pi) /\left(N_{E} U_{E}^{\prime}\left(N_{E}\right)-\pi W_{E}^{\prime}(\pi)\right)$. Thus if $W_{I}(\pi)=\tilde{W}_{I}(\pi)+\omega_{I}(\pi-\hat{\pi})$, then $\tau^{*}=\left(\tilde{W}_{I}^{\prime}(\pi)+\omega_{I}\right) /\left(N_{E} U_{E}^{\prime}\left(N_{E}\right)-\pi W_{E}^{\prime}(\pi)\right)$. At $\mathrm{q}=0$, the values of $\pi$ and $N_{E}$ are unaffected by $\omega_{I}$, so $\frac{\partial \tau^{*}}{\partial \omega_{I}}=\frac{1}{N_{E} U_{E}^{\prime}\left(N_{E}\right)-\pi W_{E}^{\prime}(\pi)}>0$. If $W_{E}(\pi)=\widetilde{W}_{E}(\pi)-\omega_{E}(\pi-\hat{\pi})$, then at $\mathrm{q}=0$, the values of $\pi$ and $N_{E}$ are unaffected by 
$\omega_{E}, \quad$ so $\quad \frac{\partial \tau^{*}}{\partial \omega_{E}}=-\frac{W_{I}^{\prime}(\pi) \pi}{\left(N_{E} U_{E}^{\prime}\left(N_{E}\right)-\pi W_{E}^{\prime}(\pi)\right)^{2}}<0 . \quad$ Finally, if $U_{E}\left(N_{E}\right)=\widetilde{U}_{E}\left(N_{E}\right)+\mu_{E}\left(N_{E}-\hat{N}_{E}\right)$, then the values of $\pi$ and $N_{E}$ are unaffected by $\mu_{E}$, so $\frac{\partial \tau^{*}}{\partial \omega_{E}}=-\frac{W_{I}^{\prime}(\pi) N_{E}}{\left(N_{E} U_{E}^{\prime}\left(N_{E}\right)-\pi W_{E}^{\prime}(\pi)\right)^{2}}<0$.

Proof of Proposition 4: Differentiation yields $\frac{\partial \pi^{\prime}(0)}{\partial \tau}=-\frac{\pi}{c^{\prime}(\pi)+W_{L}^{\prime}(\pi)-W_{M}^{\prime}(\pi)}<0$, so the condition in Proposition 1, Part (b) is satisfied. The parameters, $\kappa, \omega_{L}$ and $\omega_{M}$ do not impact $\tilde{\pi}$. Finally, differentiation also tells us that $\frac{\partial \pi^{\prime}(0)}{\partial \kappa}, \frac{\partial \pi^{\prime}(0)}{\partial \omega_{L}}$ and $\frac{\partial \pi^{\prime}(0)}{\partial \omega_{M}}$ all equal $\frac{1+\tau \pi}{\left(c^{\prime}(\pi)+W_{L}^{\prime}(\pi)-W_{M}^{\prime}(\pi)\right)^{2}}$ which is positive.

Proof of Proposition 5: An increase in q increases the welfare of laborers if and only if $\left(W_{L}^{\prime}(\pi)+\tau q\right) \frac{\partial \pi}{\partial q}+\tau \pi>0$. Substituting in for $\frac{\partial \pi}{\partial q}$, this is positive at $\mathrm{q}=0$ if and only if $h(\tau)=\tau \hat{\pi}\left(c^{\prime}(\hat{\pi})-W_{M}^{\prime}(\hat{\pi})\right)-W_{L}^{\prime}(\hat{\pi})>0$. When $\tau$ equals $W_{L}^{\prime}(\hat{\pi}) / \hat{\pi}\left(c^{\prime}(\hat{\pi})-W_{M}^{\prime}(\hat{\pi})\right)$, then $h(\tau)$ equals zero, and $h^{\prime}(\tau)=\hat{\pi}\left(c^{\prime}(\hat{\pi})-W_{M}^{\prime}(\hat{\pi})\right)>0$. This implies that at levels of $\tau$ above $W_{L}^{\prime}(\hat{\pi}) / \hat{\pi}\left(c^{\prime}(\hat{\pi})-W_{M}^{\prime}(\hat{\pi})\right)$, the laborers are helped by redistribution and for levels of $\tau$ below $W_{L}^{\prime}(\hat{\pi}) / \hat{\pi}\left(c^{\prime}(\hat{\pi})-W_{M}^{\prime}(\hat{\pi})\right)$ the laborers are hurt by redistribution.

$$
\begin{gathered}
\text { Differentiation tells us that } \quad \frac{\partial \tau^{*}}{\partial \omega_{L}}=\frac{1}{\hat{\pi}\left(c^{\prime}(\hat{\pi})-W_{M}^{\prime}(\hat{\pi})\right)}>0, \\
\frac{\partial \tau^{*}}{\partial \omega_{M}}=\frac{-W_{L}^{\prime}(\hat{\pi})}{\hat{\pi}\left(c^{\prime}(\hat{\pi})-W_{M}^{\prime}(\hat{\pi})\right)^{2}}<0 \text { and } \frac{\partial \tau^{*}}{\partial \kappa}=\frac{-W_{L}^{\prime}(\hat{\pi})}{\hat{\pi}\left(c^{\prime}(\hat{\pi})-W_{M}^{\prime}(\hat{\pi})\right)^{2}}<0 .
\end{gathered}
$$




\section{References}

Abrams, Mark, and Richard Rose, 1960, Must Labour Lose?, London: Penguin.

Acemoglu, Daron, and James Robinson, 2000, "Political Losers as a Barrier to Economic Development," American Economic Review Papers and Proceedings 90, 126-130.

Acemoglu, Daron, and James Robinson 2002, "Economic Backwardness in Political Perspective," MIT Mimeo.

Akerlof, George, and Rachel Kranton (2000), "Economics and Identity," Quarterly Journal of Economics 115, 715-754.

Alesina, Alberto, Reza Baqir, and William Easterly, 1999, "Public Goods and Ethnic Divisions," Quarterly Journal of Economics114, 1243-84.

Alesina, Alberto, Reza Baqir, and William Easterly, 2000, "Redistributive Public Employment," Journal of Urban Economics 48, 219-241.

Alesina, Alberto, and Dani Rodrik, 1994, "Distributive Politics and Economic Growth," Quarterly Journal of Economics 109, 465-490.

Alesina, Alberto, and Howard Rosenthal, 1995, Partisan Politics, Divided Government, and the Economy, Cambridge, U.K.: Cambridge University Press.

Annual Abstract of Statistics, 1952, 1972, and 1982, Longon, U.K.: Her Majesty's Stationery Office.

Barker, Rodney, 1972, Education and Politics, 1900-1951: A Study of the Labour Party, Oxford: Oxford University Press.

Beatty Jack, 1992, The rascal king: the life and times of James Michael Curley, 18741958. Reading: Addison-Wesley.

Brennan, Geoffrey and James Buchanan (1980), The Power to Tax: Analytical Foundations of the Fiscal Constitution, Cambridge, U.K.: Cambridge University Press.

Butler, David and Donald Stokes, 1974, Political Change in Britain: The Evolution of Electoral Choice, London: St. Martin's Press.

Cannadine, David, 1999, Rise and Fall of Class in Britain, New York: Columbia University Press.

Chafets, Zeev, 1991, Devil's night: and other true tales of Detroit, New York: Vintage Books. 
Coate, Stephen, and Stephen Morris, 1995, "On the Form of Transfers to Special Interests," Journal of Political Economy 103, 1210-1236.

Crewe, Ivore, Anthony Fox, and Neil Day, 1995, The British Electorate 1963-1992, A Compendium of Data from British Election Studies. Cambridge: Cambridge Univ. Press.

Curley, James Michael, 1957, I’d do it again, Englewood Cliffs: Prentice-Hall.

De Long, J. Bradford, and Andrei Shleifer, 1993, "Princes and Merchants: European City Growth Before the Industrial Revolution," Journal of Law and Economics 36, 671-702.

Edgell, Stephen, and Vic Duke, 1991, A Measure of Thatcherism: A Sociology of Britain, London: Harper Collins Academic.

Fiorina, Morris, 1981, Retrospective Voting in American National Elections, New Haven: Yale University Press.

Gamm, Gerald, 1999, Urban Exodus: Why the Jews Left Boston and the Catholics Stayed, Cambridge, MA: Harvard University Press.

Glaeser, Edward and Joseph Gyourko, 2002, “The Impact of Zoning on Housing Affordability.” NBER Working Paper W8835.

Glaeser, Edward, Matthew E. Kahn, and Jordan Rappaport, 2000, "Why Do The Poor Live In Cities?” NBER Working Paper W7636

Goldthorpe, John, David Lockwood, Frank Bechhoffer, and Jennifer Platt, 1968, "The Affluent Worker: Political Attitudes and Behavior," Cambridge: Cambridge Univ. Press.

Grossman, Gene and Elhanan Helpman, 2001, Special Interest Politics, Cambridge, MA: MIT Press.

Jacoby, Tamara, 1988, Someone Else's House, New York: Free Press.

Krusell, Per, and Jose-Victor Rios-Rull, 1996, Vested Interests in the Theory of Growth and Stagnation, Review of Economic Studies 63, 301-329.

Meredith, Martin, 2002, Our Votes, Our Guns: Robert Mugabe and the Tragedy of Zimbabwe, New York: Public Affairs.

O’Connor, Thomas H., 1995, The Boston Irish: a Political History, Boston: Northeastern University Press. 
Olson, Mancur, 1993, "Dictatorship, Democracy, and Development," American Political Science Review 87, 567-576.

Parente, Stephen, and Edward Prescott, 1999, "Monopoly Rights: a Barrier to Riches," American Economic Review 89, 1216-1233.

Persson, Torsten and Guido Tabellini, 1994, "Is Inequality Harmful to Growth? Theory and Evidence," American Economic Review 84, 600-621.

Robinson, James, and Thierry Verdier, 2002, "The Political Economy of Clientelism," CEPR Working Paper DP3205.

Shleifer, Andrei, and Robert W. Vishny, 1994,"Politicians and Firms," Quarterly Journal of Economics 109, 995-1025.

Statistical Abstract of the United States, 1982, Washington: U.S. Government Printing Office.

Sugrue, Thomas J., 1996, The Origins of the Urban Crisis: race and inequality in postwar Detroit. Princeton: Princeton University Press.

Tiebout, Charles M., 1956, "A Pure Theory of Local Government Expenditures," Journal of Political Economy 60, 415-424.

Verba, Sidney, Bashiruddin Ahmed, and Anil Bhatt, 1971, Caste, Race, and Politics, Beverley Hills: Sage Publications. 